\title{
DEVELOPMENT POTENTIAL OF NAGARA BEAN (Vigna unguiculata ssp. Cylindrica) CULTIVATED IN FRESHWATER SWAMPLANDS FOR PROCESSED FOOD
}

\author{
Rini Hustiany ${ }^{1}$, Emy Rahmawati ${ }^{2}$, Alia Rahmi ${ }^{1}$ \\ 1Department of Agricultural Technology, Lambung Mangkurat University, Banjarbaru, Indonesia \\ 2Department of Agribusiness, Lambung Mangkurat University, Banjarbaru, Indonesia \\ Jl. Jend. A. Yani KM 36 Banjarbaru, Indonesia \\ Email : hustiany@yahoo.com
}

\begin{abstract}
Nagara bean/ catjang (Vigna unguiculata spp. Cylindrica) is a subspecies of cowpea which is widely cultivated in freshwater swamplands of Daha Utara and Daha Selatan sub-districts, Hulu Sungai Selatan Regency. Nagara bean is a plant native to South Kalimantan, but its utilization is still very low compared to other cowpeas. The aims of this study were to analyze the chemical and physical characteristics of Nagara bean in processed food compared to those of soybeans; and to analyze the development potential of Nagara bean in processed food. The methods were the production of catjang flour from skinless Nagara beans; the production of catjang flour by roasting Nagara beans; the substitution of Nagara beans with coagulated and fermented soybeans. The results showed that the flour from skinless Nagara beans contained protein $(24.16 \%)$ and carbohydrate $(61.62 \%)$, while the flour from roasted Nagara beans contained protein $(18.42 \%)$ and carbohydrate $(69.33 \%)$. When compared to soybeans, papan and arabian beans, the two types of Nagara bean, could be coagulated with a higher water content and lower protein content. When Nagara beans were fermented, the water and protein contents of fermented beans were higher than those of soybeans. It can be concluded that Nagara beans could be used in processed foods chemically. Nagara beans however absorbed water easily, so they smelled sour and unpleasant and the texture became soft.
\end{abstract}

Keywords: coagulated, fermented, flour, Nagara bean, processed food

\section{INTRODUCTION}

South Kalimantan is an area with a lot of wetlands, one of which is freshwater swampland. According to Noor (2007), freshwater swamplands are the areas with puddles throughout the year, for at least three months, with a minimum height of $50 \mathrm{~cm}$. In South Kalimantan, freshwater swamplands are found in Hulu Sungai Selatan Regency. Puddles are caused by the overflow of Barito and Nagara watersheds.

Food commodities widely cultivated in freshwater swamplands are cowpeas and sweet potatoes. The famous cowpeas and sweet potatoes in Daha Utara and Daha Selatan sub-districts are Nagara bean and Nagara sweet potatoe. Nagara bean is a typical bean commodity of South Kalimantan. It is only cultivated in Daha Utara and Daha Selatan sub-districts, Hulu Sungai Selatan Regency. The villages that produce Nagara beans are Sungai Balim, Samuda, Tambangan, Paramaian, Siang Gantung, Tanjung Selor, and Muning. The planting of Nagara beans is usually carried out in dry season when water in swamplands have receded but the soil is still moist enough for planting.

Nagara bean (Vigna unguiculata spp. Cylindrica) is a cowpea that has adapted to freshwater swamplands in South Kalimantan. The bean is small, yellowish-white, brownblack hilum, and the surface of the skin is wrinkled. Nagara bean is different from Javanese cowpea. The difference lies in the more smooth skin and larger size of javanese cowpea. It is also different from cowpea (Vigna unguiculata L. Walp) grown in California, United States (Chan and Phillips, 1994).

At this time, Nagara beans are underutilized. They are mostly used only for vegetables in curry dishes and made into fried beans or kacang kuku. Hustiany (2015) produced tempe from Nagara beans with the characteristics of slightly acidic and bitter flavor and aroma, pale broken white in color and black hilum remnants, and the texture was little soft and mushy and not as crispy as soybean tempe. The carbohydrate content in Nagara bean tempe was higher (66.46\%) than 
that in soybean tempe (39.99\%). The protein content in Nagara bean tempe was lower $(29.25 \%)$ than that in soybean tempe $(42.73 \%)$. The high carbohydrate content made Nagara bean tempe have beany flavor. In addition, according to Hustiany (2014), Nagara bean flour which was substituted for tapioca flour resulted from cross link with $5 \%$ sodium tripolyphosphate (STPP) and 2\% stearic acid at a ratio of 50: 50 could reduce the viscosity of starch and the starch was not easily damaged and broken at the time of heating.

Meanwhile, soybeans can be used into a variety of processed food products, such as soy sauce, tofu, tempe, flower tofu, protein concentrate, and protein isolate, and many others. Soybeans contain 30\% carbohydrate (15\% of which is fiber), $18 \%$ fat ( $85 \%$ of which is unsaturated fatty acid), $14 \%$ water, and $38 \%$ protein. The amount of carbohydrate content in soybeans results in beany flavor (Dupont, 2002).

The objectives of this study were to analyze (1) the chemical and physical characteristics of Nagara beans in processed food when compared to those of soybeans, and (2) the development potential of Nagara beans for processed food.

\section{MATERIALS AND METHODS}

The materials used in the study were papan and arabian varieties of Nagara bean (Vigna unguiculata spp Cylindrica) from North and South Daha Sub-districts, Hulu Sungai Selatan Regency, soybeans, and various Merck's chemicals for analysis.

\section{Flour from skinless Nagara beans}

Papan Negara beans were sorted out and then washed thoroughly before they were soaked in an alkaline solution for 3 hours to reduce the activity of trypsin inhibitors and tannins, and to eliminate the activity of haemagglutinin. The beans that had been soaked were drained and their skins were removed. The beans were directly dried in an oven at a temperature of $50^{\circ} \mathrm{C}$. The dried beans were then milled with a grinder. The bean flour was sifted with 60 mesh sieve.

\section{Flour from roasted Nagara beans}

Papan beans were sorted and washed with water. The beans were roasted for 50 minutes while stirred. The roasted Nagara beans were milled using a grinder and sieved with a 60-mesh sieve.

\section{Coagulated Nagara beans}

Papan and arabian varieties of Nagara beans were substituted with soybeans. The ratio of papan/arabian Nagara beans: soybean was (1) $1: 3$; (2) $1: 1$; (3) 1:3; (4) $100 \%$ papan Nagara beans; (5) $100 \%$ Arabian Nagara beans; and (6) $100 \%$ soybeans. They were soaked for about 5 hours to soften the beans and reduce the activity of trypsin inhibitors and tannins, and to eliminate the haemagglutinin activity, as well as the acid of the beans. The beans that had expanded and been soft were milled to get the bean porridge by the addition of water at a ratio of $1: 2$. The bean porridge was then heated until boiled. When the porridge got thick, it was added with water until it was no longer lumpy. The boiled porridge was filtered. The filtered water was accommodated, while the waste was disposed. The filtered water was added with vinegar water to coagulate the protein. The coagulated protein was inserted into the mold and pressed to remove the water.

\section{Coagulated Nagara bean flour}

Nagara beans used in the flour production were papan variety. The production of coagulated Nagara beans was described previously. The comparisons were between papan Nagara beans and soybeans with the ratio of (1) $1: 2$; (2) $1: 1$; and (3) 2:1. The coagulated Nagara beans produced were then dried using an oven at $50^{\circ} \mathrm{C}$ until dry. The result of the drying was then milled by a grinder. The bean flour was sifted by a 60 mesh sieve.

\section{Fermented Nagara bean flour}

The process of fermented Nagara beans was carried out by soaking Nagara beans which were substituted with soybean for 1 night. The comparisons of papan Nagara beans and soybeans were (1) $1: 2$; (2) $1: 1$; and (3) $2: 1$. Furthermore, the beans were milled to separate the epidermis from the meat part and to break the beans into two parts at once. The beans were milled and then washed to remove the skin. After that, the beans were drained. The beans were given tempe commercial yeast of approximately $1 \mathrm{~g}$ of yeast for $100 \mathrm{~g}$ of beans. The beans were then wrapped in banana leaves or plastic, and fermented for 1 night. The fermented Nagara beans were dried using an oven at $50^{\circ} \mathrm{C}$ until dry. The result of the drying was then milled with a grinder. The bean flour was sifted with a 60 mesh sieve. 


\section{Proximate analysis}

The proximate analysis was for water content (oven method), ash content (furnace method), fat (Soxhlet method), protein content (micro Kjeldahl method), and the carbohydrate content (by differences).

\section{Gelatinization Degree and Viscosity}

Gelatinization degree and starch viscosity were measured by RVA (Rapid Visco Amylograph) 2092435 techmaster Newport Scientific brands. Samples (water content of $11 \%$ ) were 3.38 grams and 25.12 grams of water were poured into a bowl of amilograf. The sensor arms were installed and inserted into the amilograf bowl. The initial temperature of the thermoregulatory was set at $40^{\circ} \mathrm{C}$.

\section{Chemical structure based on functional clusters (Hustiany et al., 2005)}

Changes in the chemical structure of starch could be measured qualitatively using FTIR spectrometer (Fourier Transformation Infra Red) Bruker trademark series Tensor 37 at a wave length of 400 to $4000 \mathrm{~cm}^{-1}$. Samples were mixed with $\mathrm{KBr}$ crystals with a ratio of 1 : 1 for each $50 \mathrm{mg}$. This mixture was put into a container to form a pellet. These pellets were inserted into the FTIR to be read.

\section{RESULTS AND DISCUSSION}

\section{Nagara bean flour}

For the improvement of Nagara bean utilization, Nagara beans should be previously made into flour. The production of flour could be done by soaking and removing the bean skins or by roasting the beans. The purposes of the activities were to reduce the activity of trypsin inhibitors and tannins and to eliminate the haemagglutinin activity. Another purpose was to reduce the aroma and taste of unpleasant beans.

The chemical characteristics of soaked and skinless Nagara bean flour were not much different from those of roasted Nagara bean flour (Table 1). The difference was only found in the contents of protein and carbohydrate. The skinless Nagara bean flour had higher protein but lower carbohydrate content than roasted Nagara bean flour. It is because the skins of Nagara beans that were going to be made into flour had been removed, thereby reducing the carbohydrate content in the form of fiber.

The ash content of Nagara beans ranged from 3.04 to $3.93 \%$. The fairly high ash content was presumably because the Nagara beans grew in freshwater swamplands that contained a lot of minerals, such as sulfate, iron, and phosphate (2007).

Table 1 Chemical characteristics of skinless and roasted Nagara beans (papan variety)*

\begin{tabular}{ccc}
\hline Characteristics & Skinless & Roasted \\
\hline Water Content $(\%)$ & $8.90 \pm 0.11$ & $5.73 \pm 0.02$ \\
Ash Content $(\%)$ & $3.04 \pm 0.01$ & $3.93 \pm 0.00$ \\
Protein Content $(\%)$ & $24.16 \pm 0.23$ & $18.42 \pm 0.05$ \\
Fat Content & $2.28 \pm 0.00$ & $2.59 \pm 0.08$ \\
Carbohydrate Content & $61.62 \pm 0.11$ & $69.33 \pm 0.14$
\end{tabular}

${ }^{\star}$ The average of two replications

When it was viewed from the infra-red spectrum (IR) (Figure 1), the Nagara bean flour had more $\mathrm{OH}$ clusters like shown in $\lambda 3600 \mathrm{~cm}^{-1}$ to $3200 \mathrm{~cm}^{-1}$. The $\mathrm{CH}$ cluster was shown in $\lambda 3200 \mathrm{~cm}^{-1}$ to $\lambda 2800 \mathrm{~cm}^{-1}$ and 1400 $\mathrm{cm}^{-1}$ to $1350 \mathrm{~cm}^{-1}$, and the CO cluster in $\lambda 1300 \mathrm{~cm}^{-1}$ to $1000 \mathrm{~cm}^{-1}$. It indicated that Nagara beans were hydrophilic, which meant that Nagara beans were easily bound by water, and this characteristic affected the further processing of Nagara beanss.

When it was related to the viscosity of Nagara beans in creating texture, the viscosity of Nagara beans was low and not easily broken at the time of heating. It can be seen in Figure 2, that the Nagara beans had no peak which was soaring and broken. Its peak viscosity was only $836 \mathrm{cP}$. The amilograf charts tended to be stable. The Viscosity breakage was only about $98 \mathrm{cP}$. When Nagara beans were heated continously, the final viscosity was $1269 \mathrm{cP}$. Therefore, at the time of Nagara beans were coagulated, the texture became soft and mushy.

When compared to tapioca, the initial viscosity of tapioca was $5220 \mathrm{cP}$ and when it was heated continously, the finally viscosity was $3023 \mathrm{cP}$ (Hustiany, 2014). It meant that the viscosity of tapioca was very high and could form a rigid gel while the Nagara beans could only form a gel which was soft and mushy. 


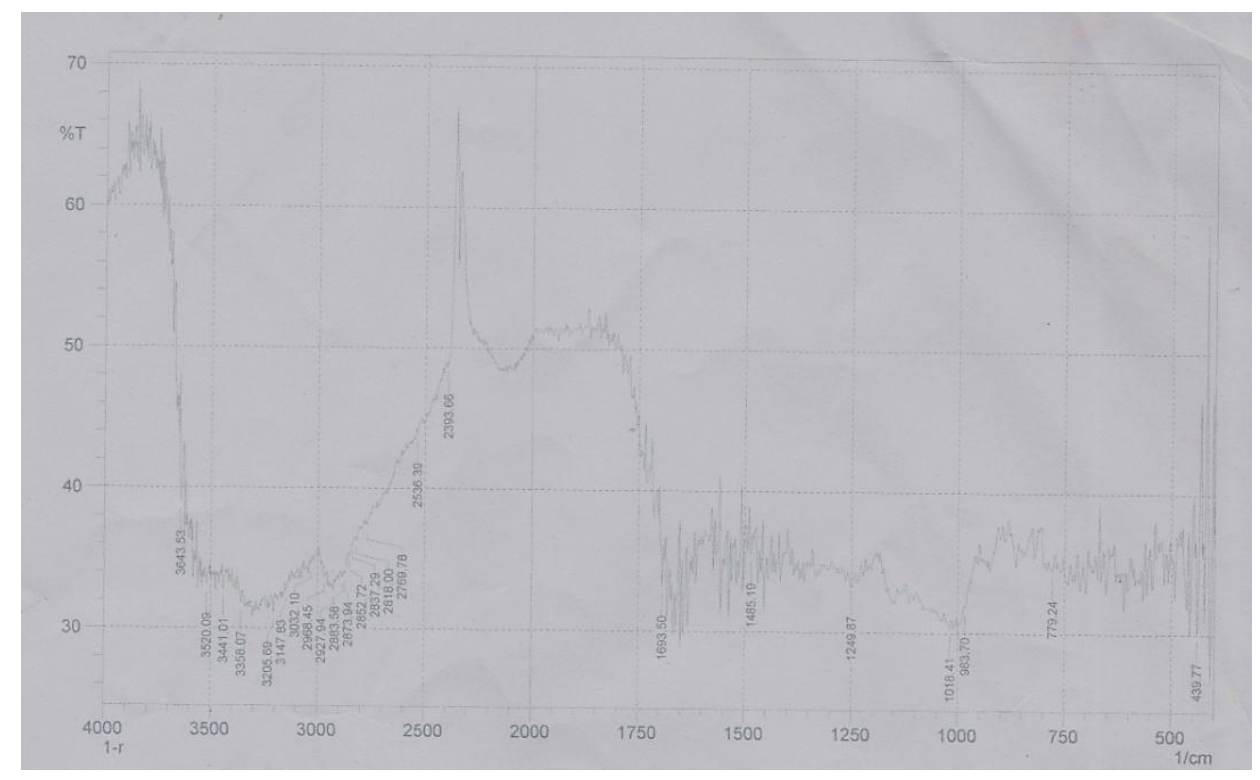

Figure 1 Infra red (IR) spectrum of skinless Nagara bean flour

\begin{tabular}{ll}
\hline Peak 1 & $836 \mathrm{cP}$ \\
Trough 1 & $738 \mathrm{cP}$ \\
Breakdown & $98 \mathrm{cP}$ \\
Final Visc & $1269 \mathrm{cP}$ \\
Setback & $531 \mathrm{cP}$ \\
Peak Time & 9.53 minutes \\
Pasting Temp & $83.35^{\circ} \mathrm{C}$ \\
Stability Rasio & 0.88 \\
Hold/Peak & \\
\hline
\end{tabular}

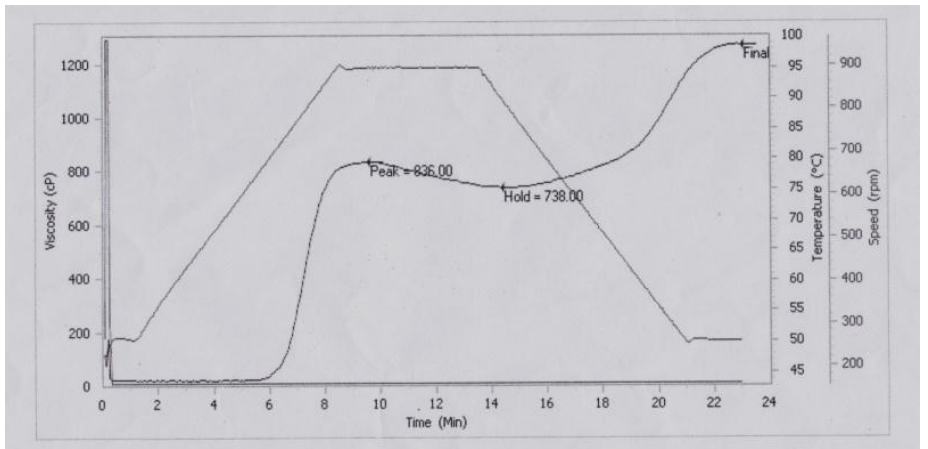

Figure 2 Amilograf curve of skinless Nagara bean flour

\section{Coagulated Nagara beans}

Nagara bean is a good protein resource. The food rich in protein that is commonly consumed by people is coagulated bean. In general, both of the arabian and papan varieties of Nagara beans could be made into coagulated beans, but the coagulated beans which were produced were soft and could not be cut like coagulated soybeans (Table 2 ).

The texture of coagulated Nagara beans was soft and mushy. This was presumably because of the characteristic of Nagara beans that easily to get bound with water; the increase in water content in Nagara beans compared to soybeans (Table 3 ). In addition, the acid and unpleasant aroma dominated Nagara coagulated beans. The more number of Nagara beans in the coagulated beans, the higher the sour and unpleasant aroma.

The water content of Nagara beans was higher (more than 84.71\%) than that of coagulated soybeans which was only $82.51 \%$ (Table 3). This indicated that the coagulated Nagara beans were easy to bind water than coagulated soybeans. The ability of Nagara beans to bind more water caused the coagulated Nagara beans texture to become soft and mushy. 
Rini Hustiany, Emy Rahmawati, Alia Rahmi : development potential of nagara

Table 2 Physical Characteristics of Nagara beans substituted with coagulated soybeans

\begin{tabular}{|c|c|}
\hline Nagara bean tofu & Characteristics \\
\hline $100 \%$ Soybean & The texture was hard and could be cut, with soy and sour aroma \\
\hline 100 \% Papan & $\begin{array}{l}\text { The texture was very soft and could not be cut, with bean aroma that was } \\
\text { a bit unpleasant and slightly sour }\end{array}$ \\
\hline $100 \%$ Arabian & $\begin{array}{l}\text { The texture was very soft, could not be cut, with bean aroma that was a bit } \\
\text { unpleasant and slightly sour }\end{array}$ \\
\hline $1: 3$ Soybean : Papan & $\begin{array}{l}\text { The texture was Mushy and could not be cut, with bean aroma,a bit } \\
\text { unpleasant }\end{array}$ \\
\hline 1: 1 Soybean : papan & $\begin{array}{l}\text { The texture was mushy and could be cut, with bean aroma that was a bit } \\
\text { unpleasant }\end{array}$ \\
\hline 3 : 1 Soybean : papan & $\begin{array}{l}\text { The texture was mushy and could be cut, with soy aroma, not unpleasant, } \\
\text { and no bean aroma }\end{array}$ \\
\hline $1: 3$ Soybean : Arabian & $\begin{array}{l}\text { The texture was mushy and could not be cut, with nut aroma, a bit sour, } \\
\text { somewhat unpleasant }\end{array}$ \\
\hline 1: 1 Soybean : Arabian & $\begin{array}{l}\text { The texture was mushy and could not be cut, with bean aroma, rather } \\
\text { unpleasant }\end{array}$ \\
\hline $3: 1$ Soybean : Arabian & The texture was hard, could be cut, sour with soy aroma \\
\hline
\end{tabular}

The ash content of coagulated Nagara beans ranged from $0.18 \%$ to $0.32 \%$ (Table 3 ). Based on Table 3 , the ash content of coagulated soybeans $(0.4 \%)$ higher than coagulated Nagara beans. This was because of the calculation using the percentage unit of wet weight. The percentage of ash content increased because the water content of coagulated soybeans was lower than that of coagulated Nagara beans.

The fat content of coagulated Nagara beans ranged from 1.15 to $5.29 \%$ lower than the fat content of coagulated soybeans at $7.11 \%$ (Table 3). The more soybeans were substituted, the more the fat content of coagulated Nagara beans increased.

Table 3 Chemical characteristics of various varieties of Nagara beans substituted with coagulated soybeans*

\begin{tabular}{ccccc}
\hline Varieties of Beans & \multicolumn{4}{c}{ Chemical Characteristics } \\
\cline { 2 - 5 } & $\begin{array}{c}\text { Water Content } \\
(\%)\end{array}$ & $\begin{array}{c}\text { Ash Content } \\
(\%)\end{array}$ & $\begin{array}{c}\text { Fat Content } \\
(\%)\end{array}$ & $\begin{array}{c}\text { Protein Content } \\
(\%)\end{array}$ \\
\hline Soybeans & $82.51 \pm 0.72$ & $0.40 \pm 0.01$ & $7.11 \pm 0.07$ & $13.08 \pm 0.63$ \\
Papan Nagara beans & $93.88 \pm 0.47$ & $0.19 \pm 0.09$ & $2.21 \pm 0.05$ & $3.62 \pm 1.17$ \\
Arabian Negara beans & $92.75 \pm 0.07$ & $0.18 \pm 0.03$ & $2.15 \pm 0.17$ & $4.57 \pm 0.99$ \\
3 Soybeans : 1 Papan & $85.64 \pm 0.18$ & $0.31 \pm 0.01$ & $5.29 \pm 0.08$ & $8.40 \pm 0.00$ \\
1 Soybeans : 3 Papan & $90.24 \pm 0.11$ & $0.19 \pm 0.00$ & $4.60 \pm 1.78$ & $9.74 \pm 0.00$ \\
1 Soybeans : 1 Papan & $85.83 \pm 0.06$ & $0.28 \pm 0.00$ & $4.32 \pm 1.91$ & $4.67 \pm 1.06$ \\
3 Soybeans : 1 Arabian & $84.71 \pm 0.32$ & $0.32 \pm 0.03$ & $3.15 \pm 0.19$ & $9.19 \pm 0.61$ \\
1 Soybeans : 3 Arabian & $90.48 \pm 0.25$ & $0.28 \pm 0.06$ & $1.15 \pm 0.01$ & $6.05 \pm 0.00$ \\
1 Soybeans : 1 Arabian & $87.99 \pm 0.13$ & $0.26 \pm 0.02$ & $1.66 \pm 0.02$ & $5.92 \pm 0.25$ \\
\hline
\end{tabular}

* The average of two replications

The protein content of coagulated Nagara beans ranged from $3.62 \%$ to $9.74 \%$ (Table 3). The protein content of coagulated Nagara beans was lower than the coagulated soybeans, $13.08 \%$ (Table 3). The more soybeans substituted into nagara beans, the more increasing the protein content of coagulated Nagara beans.

\section{Coagulated and Fermented Bean Flour}

The water content of coagulated and fermented Nagara bean flour which was substituted with soybeans could be seen in Table 4 and 5 . The water content of coagulated and fermented Nagara bean flour ranged from 5.62 to $11.42 \%$. The water content of coagulated Nagara bean flour was lower than fermented Nagara bean flour. This was because macromolecular structure of fermented Nagara bean flour was denser than macromolecular structure of coagulated Nagara bean flour. The fiber of fermented Nagara bean flour was still available in the flour at the time of fermentation. As a result, the structure of fermented bean flour was denser and harder to release water. Meanwhile, the fiber of coagulated Nagara bean flour was already separated before the 
process of coagulation. Therefore, coagulated bean flour was more porous and easier to release the water.

Table 4 Chemical characteristics of papan Nagara bean flour substituted with coagulated soybeans*

\begin{tabular}{cccccc}
\hline $\begin{array}{c}\text { Comparison of } \\
\text { Soybeans and } \\
\begin{array}{c}\text { Papan Nagara } \\
\text { Beans }\end{array}\end{array}$ & $\begin{array}{c}\text { Water Content } \\
(\%)\end{array}$ & $\begin{array}{c}\text { Ash Content } \\
(\%)\end{array}$ & $\begin{array}{c}\text { Fat Content } \\
(\%)\end{array}$ & $\begin{array}{c}\text { Protein Content } \\
(\%)\end{array}$ & $\begin{array}{c}\text { Carbohydrate } \\
\text { Content (\%) }\end{array}$ \\
\hline $2: 1$ & $5.62 \pm 0.07$ & $2.85 \pm 0.03$ & $21.67 \pm 0.16$ & $48.74 \pm 2.72$ & $21.12 \pm 2.37$ \\
$1: 1$ & $7.56 \pm 0.00$ & $3.55 \pm 0.00$ & $15.18 \pm 0.60$ & $35.38 \pm 3.67$ & $38.33 \pm 3.05$ \\
$1: 2$ & $9.14 \pm 0.03$ & $2.96 \pm 0.02$ & $8.20 \pm 0.35$ & $32.03 \pm 0.12$ & $47.67 \pm 0.39$ \\
\hline
\end{tabular}

${ }^{\star}$ The average of two replications

The more Nagara beans were added, the higher the water content of coagulated and fermented Nagara bean flour. This suggested that the presence of Nagara beans made it easy to bind with water or in other words Nagara beans was hydrophilic.

The mineral content of Nagara bean flour was higher than that of the fermented Nagara bean flour. The ash content of coagulated Nagara bean flour ranged between 2.85 to $3.55 \%$, while the fermented Nagara bean flour ranged between 1.47 to $1.78 \%$ (Table 4 and 5 ). High content of ash in coagulated Nagara bean flour was presumably because the mineral found in Nagara beans did not bind to the dregs before coagulation. But the mineral in Nagara beans were also filtered together with the filtrate which was going to be coagulated. Therefore, the ash content of coagulated Nagara bean flour almost the same as skinless Nagara bean flour or roasted Nagara bean flour.

The mineral content of fermented Nagara bean flour decreased when compared with skinless Nagara bean flour or roasted Nagara bean flour. This was presumably because of the process of washing, soaking and boiling before the fermentation process that was able to dissolve the mineral in the beans. The decreased content of ash after the fermentation process also occured in barley. Before the fermentation was done, the ash content of barley was $2.16 \%$ (Khokhar et al., 2010). After the fermentation, the ash content of fermented barley was $0.9 \%$ (Alminger and Eklund-Jonsson, 2008).

Table 5 Chemical characteristics of papan Nagara bean flour substituted with fermented soybeans*

\begin{tabular}{cccccc}
\hline Comparison of & \multicolumn{5}{c}{ Chemical Characteristics } \\
\cline { 2 - 6 } $\begin{array}{c}\text { soybeans and } \\
\text { papan Nagara } \\
\text { beans }\end{array}$ & $\begin{array}{c}\text { Water Content } \\
(\%)\end{array}$ & $\begin{array}{c}\text { Ash Content } \\
(\%)\end{array}$ & $\begin{array}{c}\text { Fat Content } \\
(\%)\end{array}$ & $\begin{array}{c}\text { Protein } \\
\text { Content (\%) }\end{array}$ & $\begin{array}{c}\text { Carbohydrate } \\
\text { Content }(\%)\end{array}$ \\
\hline $2: 1$ & $6.19 \pm 0.14$ & $1.76 \pm 0.01$ & $17.33 \pm 0.70$ & $27.83 \pm 9.31$ & $46.88 \pm 8.44$ \\
$1: 1$ & $11.42 \pm 0.01$ & $1.78 \pm 0.02$ & $14.68 \pm 1.09$ & $30.03 \pm 1.21$ & $42.09 \pm 2.17$ \\
$1: 2$ & $10.61 \pm 0.09$ & $1.47 \pm 0.00$ & $13.06 \pm 0.18$ & $30.58 \pm 6.22$ & $44.28 \pm 6.45$ \\
\hline
\end{tabular}

${ }^{*}$ The average of two replications

Fat content of coagulated Nagara bean flour ranged between 8.2 to $21.67 \%$, while the fat content of fermented Nagara bean flour from 13.06 to $17.33 \%$ (Tables 4 and 5). The fat content of coagulated Nagara bean flour tended to be higher than the fermented Nagara bean flour. The washing, soaking and boiling in the production of fermented Nagara bean flour made the fat of the beans also dissolved, so the fat content of fermented Nagara bean flour could decrease.

Soybeans in the production of coagulated and fermented bean flour could increase the fat content of coagulated and fermented Nagara bean flour. The higher the amount of soybeans substituted, the higher the fat content contained in coagulated and fermented Nagara beans flour.

The process of washing, soaking and boiling the beans in the production of fermented Nagara beans also caused the decrease in protein content of fermented Nagara bean flour. The protein content of fermented Nagara bean flour was relatively lower than the bean flour. The protein content of coagulated Nagara bean flour ranged from 32.03 up to $48.74 \%$, while the protein content of fermented Nagara bean flour ranged from 
27.83 to $30.58 \%$ (Table 4 and 5). The presence of soybeans in coagulated Nagara bean flour could increase the protein content of coagulated Nagara bean flour. The protein content of fermented Nagara beans tended to be higher compared to skinless or roasted bean flour. It could be because biosynthesis of protein with the help of fungi occured during the fermentation process.

Carbohydrate content of coagulated Nagara bean flour tended to be lower than fermented Nagara bean flour. This was because the protein and fat contents of coagulated Nagara bean flour tended to be higher than the fermented Nagara bean flour. Carbohydrate content of coagulated Nagara bean flour ranged from 21.12 to $47.67 \%$ (Table 4), while the carbohydrate content of fermented Nagara bean flour ranged from 42.09 to $46.88 \%$ (Table 5). According to Hustiany (2015) the high content of carbohydrate could lead to the formation of acid aroma and soft texture.

\section{CONCLUSIONS}

Nagara beans are the beans that are easy to bind water with lower protein and higher carbohydrate content compared to soybeans. Nagara beans contain many $\mathrm{OH}$ clusters, so they are easy to bind water. The texture of Nagara bean is soft and mushy and the viscosity is stable at the time of heating.

Nagara beans could be fermented, and also formed into gel by coagulation. Nagara beans could be chemically used for processed food, but they easily absorbed water, so it could smell sour and unpleasant and the texture became soft.

\section{REFERENCES}

Alminger, M. \& Eklund-Jonsson, C. (2008). Whole-grain Cereal Products Based on a High-fibre Barley or Oat Genotype Lower Post-prandial Glucose and Insulin Responses in Healthy Humans. Eur $J$ Nutr. 47:294-300.

Chan, C-W. \& Phillips, R.D. (1994). Amino Acid Composition and Subunit Constitution of Protein Fraction from Cowpea (Vigna unguiculata L. Walp) Seeds. Journal Agriculture Food Chemical 42 (9):1857-1860.

Dupont (2002). Soy Protein Forms. Retrieved from www.protein.com.
Hustiany, R., Fardiaz, D., Apriyantono, A. \& Andarwulan, N. (2005). Acylation Modification and Suksinilasi of Tapioca Starch. Journal Teknol and Food Industry XVI (3): 206-214.

Hustiany, R. (2014). Characteristics of Crosslink Acylation Tapioca Substituted Nagara Beans (Vigna unguiculata spp. Cylindrica) Flour. Agroindustrial Journal 3 Issue 1: 125-132.

Hustiany, R. (2015). Potential of Nagara Pea (Vigna unguiculata spp. Cylindrica) for Processed Food of Tempe. Prossiding Seminar Nasional SPRINT 2014. Yogyakarta. ISBN 978-602-70784-1-3.

Khokhar, Z., Athar, M. A., Syed, Q-A., Baig, S., Nadeem, M., Sher, M. G., Ali, S. \& Islam, I. (2010). Studies on the Development of Value Added Food by Rhizopus Oligosporus in Koji Fermentation. Sci.Int (Lahore) 22 (3):219-226.

Noor, M. (2007). Freshwater Swamps. Ecology, Utilization, and Development. PT. Raja Grafindo Persada. Jakarta. 